\title{
Mother's Education and her Knowledge about Home Accident Prevention among Preschool Children in Rural Area in Sharkia Governorate
}

\author{
Amirat Ali El-Sabely ${ }^{1}$, Abd El-Aziz Ismail Yassin ${ }^{2}$, and Salwa Ahmed Zaher ${ }^{3}$ \\ ${ }^{1}$ Department of Pediatric health Nursing, Faculty of Nursing, Zagazig University, Egypt \\ ${ }^{2}$ Department of Community Medicine, Faculty of Medicine, Tanta University, Egypt \\ ${ }^{3}$ Department of Nursing, College of Applied Medical Science, Salman Bin Abd El-Aziz University, Saudi
}

\begin{abstract}
Unintentional injury remains the leading cause of morbidity and mortality among children worldwide. The aim of this study was to describe the mother's education and her knowledge in relation to home accidents prevention in rural area in Sharkia Governorate. Study design, a cross-sectional descriptive study design was adopted in this study. The sample size was 150 mothers from Kafr Mohsen village, this number was drawn by a systematic random by visiting every 5 house in the village, those mother's were inter-viewed in their homes through home visits. Structured interview sheet was developed based on relevant literature, it contained the following data: A) The first part included socio-demographic characteristics of the families as mother's age, educational level, occupation, family size and number of children .B) The second part included mother knowledge towards home accidents among children and its occurrence, types and mother's knowledge regarding causes of home accidents. C) The third part included mother's practice or first aid measures she followed towards her child in case of exposure to any type of home accidents. The study result indicated that, the mean age of the mothers was $(34.1 \pm 9.6)$ years. Regarding educational level, $33.3 \%$ had completed university education, while $25.3 \%$ of them were illiterate. Occupational status showed that more than one half of the studied mothers (58\%) didn't work, while 14\% worked as health care personnel. $61.3 \%$ were of middle socio economic status. More than half of the injured children (59.3\%) were aged 3years or less, over half of them (58.7\%) were males. The majority of the mothers (84.7\%) reported that the child had suffered an injury at home. Cut/wound represented the highest percentage of home injury (37.3\%) followed by fall (29.3\%), burn (12\%), animal bite (3.3\%) then poisoning (1.3\%). The study revealed that the majority of mothers $(80 \%)$ heard of the term of first aid and the main source of their knowledge was from "radio and television" (24\%) then "doctors and nurses" (15.3\%), "part of curriculum" nearly (14\%) and the lowest source was from "books" (6.7\%). More than half of the studied mothers (55.3\%) did not have any knowledge about the causes of home accidents. the relation between mother's age and her knowledge regarding causes of home accidents was proved to be statistically non significant ( $p>0.05$ ). mother's knowledge regarding causes of home accidents increased with increasing educational level. The relation was proved to be statistically significant $(p<0.001)$. The conclusion of this study revealed that, well educated mothers will use the proper first aid. So there is need for parent's educational programs especially mothers with preschool children about home accidents and how to manage.
\end{abstract}

Key words: Mother's Education, Home Accident Prevention, Preschool Children

\section{Introduction}

Injuries and accidents are the leading causes of death in children worldwide (Krug et., al 2000). Children are prone to unintentional injuries and are at a higher risk of experiencing injuries, because their bodies are developing and they have not yet learned to be aware both of themselves and various environmental dangers (Bruce and McGrath, 2005). In Egypt too it has become a concern. For example, in 1998 the overall rate of injuries in the indoor home environment was $72.5 \%$ among children below age 5 years (Amin et., al, 1998). The incidence of home accidents among children under 6 years in Assuit governorate in the year 2003 as perceived by their mothers was 50.3\% (Abd El-Aty et al, 2005). According to the National Safe Kids Campaign in the United States, $40 \%$ of deaths and 50\% of non-fatal unintentional injuries occur in and around the home (National Safe Kids Campaign, 2012). A child's environment plays a critical role, both in the occurrence and the severity of an injury. Most injuries take place in or near a child's home (WHO Issue Brief Series, 2013). The most Common injuries include: drowning, falls, fires or burns, poisoning, suffocation, and transportation-related injuries ( Home Accident Presentation Strategy \& Action Plan 2004 - 2009). Prevention and control of home accidents among children has been recently a target and very important area for health promotion(Abd El Wahed, et al., 2000) . First aid is the provision of initial care for an illness or injury, usually by a non-expert but trained person, until medical treatment can be accessed. Provision of immediate first aid to patients who require emergency care can make a big difference to the outcome [Tomruk et al, 2007], as the first action taken for management of 
injuries and common illness decides the future course of disease and complication rates [Hecht , 2012]. Parents' knowledge and practice about first aid is especially important in injury care for children, as many adverse consequences of injuries can be averted if parents know what actions to take, (Ibrahim , 1991). It is a true saying that education improves people's ways of life and gives way for enlightenments, (National safe kids campaign,(2000). Ignorance and negligence of the mother are the fundamental causes of accidents. So it is important to improve the mother knowledge, attitude and practice to prevent accidents at home. Education is an important nursing role and was the primary intervention strategy chosen to address and prevent childhood home injuries. The nurse will try to ensure that people know how to prevent accidents and injuries in their communities, at homes, schools and work places.

\section{Aim of the study:}

This study aimed to describe the effect of mother's education and her knowledge about home accidents prevention among preschool children in rural area in Sharkia Governorate.

Research question:

What is the relation between mother's education and her knowledge about home accidents prevention?

\section{Subject And Methods:}

Design:

A cross-sectional descriptive study was adopted in this study to describe the effect of mother's education and age in relation to home accident prevention among preschool children in rural area in Sharkia Governorate.

Setting: Subjects:

The study was conducted at Kafr Mohsen village in Sharkia Governorate

The sample size was 150 mothers from Kafr Mohsen village, this number was drawn by a systematic random by visiting every 5 house in the village, those mother's were inter-viewed in their homes through home visits.

Tools:

Structured interview sheets was developed based on relevant literature to describe the effect of mother's education and age in relation to home accidents prevention, it contained the following data:

A) The first part:

It included socio-demographic characteristics of the families as mother's age, educational level, occupation, and family size.

B) The second part:

It included mother's knowledge towards home accidents among children and its occurrence, types and mother's knowledge regarding causes of home accidents.

C) The third part:

It included mother's practice or first aid measures she followed towards her child in case of exposure to any type of home accidents.

Pilot Study:

A pilot study was carried out before performing the actual study on ten mothers in order to test the validity and clarity of the tools items as well as to estimate the time needed for data collection, the necessary modifications were done, and those participants were excluded from the sample.

\section{Methods:}

1- Ethical approval:

A written informed consent (in Arabic language) was obtained from mothers before participation.

2- Data collection technique:

Data collected through home visits by interviewing every mother individually at her home to identify her knowledge and practice towards home accidents prevention. The average number interviewed was 3-5 cases per day and average time taken for completing each sheet was around 20-30 minutes, this was depending on the response of the mothers

\section{Study period:}

Data was collected over a period of two months (July \& August 2013).

\subsection{Statistical methods}

The collected data were tabulated and analyzed using SPSS statistical package version 20. Qualitative variables were presented as frequencies and percentages. Chi-square test was used to test significance. Significance level used was 0.05 . 


\section{Results}

TABLE-1

Distribution of the mothers by selected socio demographic characteristics

\begin{tabular}{|c|c|c|}
\hline characteristics & $\mathrm{No}=150$ & Percent \\
\hline $\begin{array}{l}\text { Mother's age: } \\
<25 \text { years } \\
25-<35 \\
35-<45 \\
\geq 45\end{array}$ & $\begin{array}{l}29 \\
53 \\
46 \\
22\end{array}$ & $\begin{array}{l}19.3 \\
35.3 \\
30.7 \\
14.7\end{array}$ \\
\hline Mean \pm SD & & \\
\hline $\begin{array}{l}\text { Mother's education: } \\
\text { University education } \\
\text { Secondary education } \\
\text { Preparatory education } \\
\text { Read \& write } \\
\text { Illiterate } \\
\end{array}$ & $\begin{array}{l}50 \\
41 \\
11 \\
10 \\
38\end{array}$ & $\begin{array}{c}33.3 \\
27.3 \\
7.3 \\
6.7 \\
25.3 \\
\end{array}$ \\
\hline $\begin{array}{l}\text { Mother's occupation: } \\
\text { Working at health sector } \\
\text { Other jobs } \\
\text { Not working }\end{array}$ & $\begin{array}{l}21 \\
42 \\
87 \\
\end{array}$ & $\begin{array}{l}14.0 \\
28.0 \\
58.0\end{array}$ \\
\hline $\begin{array}{l}\text { Family size } \\
\text { Three members } \\
\text { Four members } \\
\text { Five members } \\
\text { Six members } \\
\text { Seven or more members }\end{array}$ & $\begin{array}{l}57 \\
35 \\
28 \\
17 \\
13\end{array}$ & $\begin{array}{c}38.0 \\
23.3 \\
18.7 \\
11.3 \\
8.7 \\
\end{array}$ \\
\hline $\begin{array}{l}\text { Socioeconomic status } \\
\text { High } \\
\text { Middle } \\
\text { Low }\end{array}$ & $\begin{array}{l}19 \\
92 \\
39\end{array}$ & $\begin{array}{l}12.7 \\
61.3 \\
26.0\end{array}$ \\
\hline
\end{tabular}

Table 1 show that the mean age of the mothers was (34.1 \pm 9.6$)$ years. Regarding educational level, $33.3 \%$ had completed university education, while $25.3 \%$ of them were illiterate. Occupational status showed that more than one half of the studied mothers (58\%) didn't work, while $14 \%$ worked as health care personnel. According to family size, the present study showed that $38 \%$ of families had three members and $61.3 \%$ were of middle socio economic status.

TABLE-2

Distribution of the studied sample of mothers and their children suffering injury by their age, sex, and type of injury

\begin{tabular}{|c|c|c|}
\hline Variable & $\mathrm{No}=150$ & Percent \\
\hline $\begin{array}{l}\text { Child's age (years) } \\
\leq 3 \text { years } \\
3 \leq 6 \text { years }\end{array}$ & $\begin{array}{l}89 \\
61\end{array}$ & $\begin{array}{l}59.3 \\
40.6 \\
\end{array}$ \\
\hline $\begin{array}{l}\text { Child's sex } \\
\text { Male } \\
\text { Female }\end{array}$ & $\begin{array}{l}88 \\
62\end{array}$ & $\begin{array}{l}58.7 \\
41.3\end{array}$ \\
\hline $\begin{array}{l}\text { Occurrence of home accidents: } \\
\text { Occurred } \\
\text { Not Occurred }\end{array}$ & $\begin{array}{c}127 \\
23\end{array}$ & $\begin{array}{l}84.7 \\
15.3 \\
\end{array}$ \\
\hline $\begin{array}{l}\text { Types of home accidents: } \\
\text { Cut / Wound } \\
\text { Fall / Fracture } \\
\text { Burn } \\
\text { Poisoning } \\
\text { Choking } \\
\text { Animal bite } \\
\text { Not occurred }\end{array}$ & $\begin{array}{c}56 \\
44 \\
18 \\
2 \\
2 \\
5 \\
23\end{array}$ & $\begin{array}{c}37.3 \\
29.3 \\
12.0 \\
1.3 \\
1.3 \\
3.3 \\
15.3\end{array}$ \\
\hline $\begin{array}{l}\text { Heard about first aids } \\
\text { Yes } \\
\text { No }\end{array}$ & $\begin{array}{c}120 \\
30 \\
\end{array}$ & $\begin{array}{l}80 \\
20 \\
\end{array}$ \\
\hline $\begin{array}{l}\text { Source of knowledge } \\
\text { From books } \\
\text { Part of curriculum } \\
\text { Friends and relatives } \\
\text { Doctors and nurses } \\
\text { Radio and television } \\
\text { Attend training periods } \\
\text { Not hearing }\end{array}$ & $\begin{array}{l}10 \\
21 \\
17 \\
23 \\
36 \\
13 \\
30\end{array}$ & $\begin{array}{c}6.7 \\
14.0 \\
11.3 \\
15.3 \\
24.0 \\
8.7 \\
20.0\end{array}$ \\
\hline
\end{tabular}


Table 2. reveals that more than half of the injured children $(59.3 \%)$ were aged 3years or less, over half of them $(58.7 \%)$ were males. The majority of the mothers $(84.7 \%)$ reported that the child had suffered an injury at home. Cut/wound represented the highest percentage of home injury (37.3\%) followed by fall (29.3\%), burn (12\%), animal bite $(3.3 \%)$ then poisoning $(1.3 \%)$. The study revealed that the majority of mothers $(80 \%)$ heard of the term of first aid and the main source of their knowledge was from "radio and television" (24\%) then "doctors and nurses" (15.3\%), "part of curriculum" nearly(14\%) and the lowest source was from "books" (6.7\%).

\section{TABLE-3}

Distribution of the mother's knowledge regarding to cause of home accidents in studied sample Table 3 illustrates that more than half of the studied mothers $(55.3 \%)$ did not have any knowledge about the causes of home accidents.

\begin{tabular}{|l|c|c|}
\hline $\begin{array}{l}\text { Mother's knowledge regarding causes } \\
\text { of home accident }\end{array}$ & No= 150 & Percent \\
\hline Know & 67 & 44.7 \\
\hline Do not know & 83 & 55.3 \\
\hline
\end{tabular}

TABLE-4

Distribution of mother's knowledge regarding their practices toward different types of home accidents

\begin{tabular}{|c|c|c|}
\hline Mother's practice & No. $=150$ & Percent \\
\hline $\begin{array}{l}\text { Fracture: } \\
\text { 1- Go to hospital } \\
\text { 2- Counsel relatives } \\
\text { 3- Traditional method } \\
\text { 4- More than one approach } \\
\text { 5- Don't know }\end{array}$ & $\begin{array}{c}47 \\
0 \\
1 \\
60 \\
42 \\
\end{array}$ & $\begin{array}{c}31.3 \\
0.0 \\
0.7 \\
40.0 \\
28.0\end{array}$ \\
\hline $\begin{array}{l}\text { Wound: } \\
\text { 1- Go to hospital } \\
\text { 2- Counsel relatives } \\
\text { 3- Traditional method } \\
\text { 4- More than one approach } \\
\text { 5- Don't know }\end{array}$ & $\begin{array}{c}6 \\
0 \\
4 \\
100 \\
40 \\
\end{array}$ & $\begin{array}{c}4.0 \\
0.0 \\
2.7 \\
66.6 \\
26.7 \\
\end{array}$ \\
\hline $\begin{array}{l}\text { Bleeding: } \\
\text { 1- Go to hospital } \\
\text { 2- Counsel relatives } \\
\text { 3- Traditional method } \\
\text { 4- More than one approach } \\
\text { 5- Don't know }\end{array}$ & $\begin{array}{c}0 \\
0 \\
0 \\
78 \\
72\end{array}$ & $\begin{array}{c}0.0 \\
0.0 \\
0.0 \\
52 \\
48\end{array}$ \\
\hline $\begin{array}{l}\text { Choking: } \\
\text { 1- Go to hospital } \\
\text { 2- Counsel relatives } \\
\text { 3- Traditional method } \\
\text { 4- More than one approach } \\
\text { 5- Don't know }\end{array}$ & $\begin{array}{c}30 \\
2 \\
18 \\
24 \\
76 \\
\end{array}$ & $\begin{array}{c}20.0 \\
1.3 \\
12.0 \\
16.0 \\
50.7 \\
\end{array}$ \\
\hline $\begin{array}{l}\text { Poisoning: } \\
\text { 1- Go to hospital } \\
\text { 2- Counsel relatives } \\
\text { 3- Traditional method } \\
\text { 4- More than one approach } \\
\text { 5- Don't know }\end{array}$ & $\begin{array}{c}31 \\
0 \\
25 \\
38 \\
56 \\
\end{array}$ & $\begin{array}{c}20.7 \\
0.0 \\
16.7 \\
25.3 \\
37.3 \\
\end{array}$ \\
\hline $\begin{array}{l}\text { Animal bites: } \\
\text { 1- Go to hospital } \\
\text { 2- Counsel relatives } \\
\text { 3- Traditional method } \\
\text { 4- More than one approach } \\
\text { 5- Don't know }\end{array}$ & $\begin{array}{c}19 \\
0 \\
8 \\
45 \\
78\end{array}$ & $\begin{array}{c}12.7 \\
0.0 \\
5.3 \\
30 \\
52.0\end{array}$ \\
\hline $\begin{array}{l}\text { Burn: } \\
\text { 1- Go to hospital } \\
\text { 2- Counsel relatives } \\
\text { 3- Traditional method } \\
\text { 4- More than one approach } \\
\text { 5- Don't know }\end{array}$ & $\begin{array}{c}22 \\
0 \\
11 \\
76 \\
41\end{array}$ & $\begin{array}{c}14.7 \\
0.0 \\
7.3 \\
50.7 \\
27.3\end{array}$ \\
\hline
\end{tabular}

Table 4 Shows that in case of fracture, about one third of mothers $(31.3 \%)$ went to hospital\& two fifth of them (40\%) practiced more than one approach. Regarding mothers practice in case of wound slightly more than two thirds of mothers $(66.6 \%)$ used more than one method. According to mother's practice in case of bleeding, it was 
clear that slightly more than half of mothers $(52 \%)$ used more than one method while $48 \%$ of them didn't know what to do in case of bleeding. As regards mother's practice in case of choking it was clear that nearly half of mothers $(50.7 \%)$ didn't know what to do and $20 \%$ of them went to hospital. Concerning mother's practice in case of poisoning and animal bite, it was found that the highest percentage of mothers didn't know what to do (37.3\% and $52 \%$ ) respectively. As regards mother's practice in case of burn, 50.7\% of them used more than one method.

TABLE-5

Relation between mother's education and her practice in case of poisoning and choking in studied sample

\begin{tabular}{|c|c|c|c|c|c|c|c|c|c|c|c|}
\hline \multirow{3}{*}{ Mother's practice } & \multicolumn{10}{|c|}{ Mother's education } & \multirow{3}{*}{ Total } \\
\hline & \multicolumn{2}{|c|}{ Illiterate } & \multicolumn{2}{|c|}{ Read\&write } & \multicolumn{2}{|c|}{ Preparatory } & \multicolumn{2}{|c|}{ Secondary } & \multicolumn{2}{|c|}{ University } & \\
\hline & No. & $\%$ & No. & $\%$ & No. & $\%$ & No. & $\%$ & No. & $\%$ & \\
\hline Poisoning: & & & & & & & & & & & \\
\hline 1- Go to hospital & 4 & 10.5 & 4 & 40 & 4 & 36.4 & 11 & 26.8 & 8 & 16 & 31 \\
\hline 2- Counsel relatives & 0 & 0.0 & 0 & 0.0 & 0 & 0.0 & 0 & 0.0 & 0 & 0.0 & 0 \\
\hline 3-Traditional method & 3 & 7.9 & 2 & 20 & 4 & 36.4 & 8 & 19.5 & 8 & 16 & 25 \\
\hline 4- More than one method & 1 & 2.6 & 1 & 10 & 1 & 9.1 & 9 & 22 & 26 & 52 & 38 \\
\hline 5- Don't know & 30 & 78.9 & 3 & 30 & 2 & 18.2 & 13 & 31.7 & 8 & 16 & 56 \\
\hline 6- total & 38 & 100 & 10 & 100 & 11 & 100 & 41 & 100 & 50 & 100 & 150 \\
\hline P-value & \multicolumn{11}{|c|}{0.001} \\
\hline Choking: & & & & & & & & & & & \\
\hline 1- Go to hospital & 5 & 13.2 & 3 & 30 & 3 & 27.3 & 11 & 26.8 & 8 & 16 & 30 \\
\hline 2- Counsel relatives & 1 & 2.6 & 0 & 0 & 0 & 0 & 0 & 0 & 1 & 2 & 2 \\
\hline 3- Traditional method & 2 & 5.3 & 1 & 10 & 0 & 0 & 6 & 14.6 & 9 & 18 & 18 \\
\hline 4- More than one method & 1 & 2.6 & 0 & 0 & 2 & 18.2 & 3 & 7.3 & 18 & 36 & 24 \\
\hline 5- Don't know & 29 & 76.3 & 6 & 60 & 6 & 54.5 & 21 & 51.2 & 14 & 28 & 76 \\
\hline 6- Total & 38 & 100 & 10 & 100 & 11 & 100 & 41 & 100 & 50 & 100 & 150 \\
\hline P-value & \multicolumn{11}{|c|}{0.001} \\
\hline
\end{tabular}

Table 5 clears that more than three quarters of illiterate mothers (78.9\%) did nothing regarding poisoning while more than half of highly educated mothers (52\%) practiced more than one method. The difference between mothers education and practice regarding poisoning was proved to be statistically significant ( $\mathrm{p}$ value $<0.001$ ).In case of choking more than three quarters $(76.3 \%)$ of illiterate mothers did nothing, while more than one third of highly educated mothers $(36 \%)$ did more than one method. The difference was statistically significant (p value $<0.001)$.

TABLE-6

Relation between mother's education and her practice in case of burn and fracture in studied sample

\begin{tabular}{|c|c|c|c|c|c|c|c|c|c|c|c|}
\hline \multirow{3}{*}{ Mother's practice } & \multicolumn{10}{|c|}{ Mother's education } & \multirow{3}{*}{ Total } \\
\hline & \multicolumn{2}{|c|}{ Illiterate } & \multicolumn{2}{|c|}{ Read \& write } & \multicolumn{2}{|c|}{ Preparatory } & \multicolumn{2}{|c|}{ Secondary } & \multicolumn{2}{|c|}{ University } & \\
\hline & No. & $\%$ & No. & $\%$ & No. & $\%$ & No. & $\%$ & No. & $\%$ & \\
\hline Burn: & & & & & & & & & & & \\
\hline$\overline{\text { 1- Go to hospital }}$ & 1 & 2.6 & 2 & 20 & 3 & 27.3 & 11 & 26.8 & 5 & 10 & 22 \\
\hline 2- Counsel relatives & 0 & 0.0 & 0 & 0.0 & 0 & 0.0 & 0 & 0.0 & 0 & 0.0 & 0 \\
\hline 3- Traditional method & 2 & 5.3 & 2 & 20 & 2 & 18.2 & 2 & 4.9 & 3 & 6 & 11 \\
\hline 4- More than one method & 6 & 15.78 & 4 & 40 & 5 & 45.5 & 21 & 51.2 & 40 & 80 & 76 \\
\hline 5- Don't know & 29 & 76.3 & 2 & 20 & 1 & 9.1 & 7 & 17.1 & 2 & 4 & 41 \\
\hline 6- Total & 38 & 100 & 10 & 100 & 11 & 100 & 41 & 100 & 50 & 100 & 150 \\
\hline P-value & \multicolumn{11}{|c|}{0.001} \\
\hline Fracture: & & & & & & & & & & & \\
\hline$\overline{\text { 1- Go to hospital }}$ & 5 & 13.2 & 5 & 50 & 6 & 54.5 & 18 & 43.9 & 13 & 26 & 47 \\
\hline 2- Counsel relatives & 0 & 0 & 0 & 0 & 0 & 0 & 0 & 0 & 0 & 0 & 0 \\
\hline 3- Traditional method & 0 & 0 & 0 & 0 & 0 & 0 & 1 & 2.4 & 0 & 0 & 1 \\
\hline 4- More than one method & 3 & 7.9 & 2 & 20 & 2 & 18.2 & 16 & 39 & 37 & 74 & 60 \\
\hline 5- Don't know & 30 & 78.9 & 3 & 30 & 3 & 27.3 & 6 & 14.6 & 0 & 0 & 42 \\
\hline 6- Total & 38 & 100 & 10 & 100 & 11 & 100 & 41 & 100 & 50 & 100 & 150 \\
\hline P-value & & & & & & & & & & & \\
\hline
\end{tabular}

Table (6) shows that about three quarters of illiterate mothers (76.3\%) did nothing regarding care of burn, while $(80 \%)$ of highly educated mothers practiced more than one method. The relation between mothers education and practice regarding burn was proved to be statistically significant ( $\mathrm{p}$ value $<0.001$ ). In case of fracture, more than three quarters $(78.9 \%)$ of illiterate mothers did nothing, while about three quarters of highly educated mothers $(74 \%)$ did more than one method and the relation between mothers education and practice regarding fracture was proved to be statistically significant ( $\mathrm{p}$ value $<0.001$ ). 
TABLE-7

Relation between mother's education and her practice in case of wound and bleeding in studied sample

\begin{tabular}{|c|c|c|c|c|c|c|c|c|c|c|c|}
\hline \multirow{3}{*}{ Mother's practice } & \multicolumn{10}{|c|}{ Mother's education } & \multirow{3}{*}{ Total } \\
\hline & \multicolumn{2}{|c|}{ Illiterate } & \multicolumn{2}{|c|}{ Read write } & \multicolumn{2}{|c|}{ Preparatory } & \multicolumn{2}{|c|}{ Secondary } & \multicolumn{2}{|c|}{ University } & \\
\hline & No. & $\%$ & No. & $\%$ & No. & $\%$ & No. & $\%$ & No. & $\%$ & \\
\hline wound: & & & & & & & & & & & \\
\hline$\overline{\text { 1- Go to hospital }}$ & 0 & 0 & 0 & 0 & 0 & 0 & 5 & 12.2 & 1 & 2 & 6 \\
\hline 2- Counsel relatives & 0 & 0.0 & 0 & 0.0 & 0 & 0.0 & 0 & 0.0 & 0 & 0.0 & 0 \\
\hline 3- Traditional method & 0 & 0 & 0 & 0 & 0 & 0 & 3 & 7.3 & 1 & 2 & 4 \\
\hline 4- More than one method & 9 & 23.7 & 8 & 80 & 9 & 81.8 & 28 & 68.3 & 46 & 92 & 100 \\
\hline 5- Don't know & 29 & 76.3 & 2 & 20 & 2 & 18.2 & 5 & 12.2 & 2 & 4 & 40 \\
\hline 6- Total & 38 & 100 & 10 & 100 & 11 & 100 & 41 & 100 & 50 & 100 & 150 \\
\hline P-value & \multicolumn{11}{|c|}{0.001} \\
\hline Bleeding: & & & & & & & & & & & \\
\hline 1- Go to hospital & 0 & 0.0 & 0 & 0.0 & 0 & 0.0 & 0 & 0.0 & 0 & 0.0 & 0 \\
\hline 2- Counsel relatives & 0 & 0.0 & 0 & 00. & 0 & 0.0 & 0 & 0.0 & 0 & 0.0 & 0 \\
\hline 3- Traditional method & 0 & 0.0 & 0 & 0.0 & 0 & 0.0 & 0 & 0.0 & 0 & 0.0 & 0 \\
\hline 4- More than one method & 6 & 15.8 & 3 & 30 & 8 & 72.7 & 23 & 56.1 & 38 & 76 & 78 \\
\hline 5- Don't know & 32 & 84.2 & 7 & 70 & 3 & 27.3 & 18 & 43.9 & 12 & 24 & 72 \\
\hline 6- Total & 38 & 100 & 10 & 100 & 11 & 100 & 41 & 100 & 50 & 100 & 150 \\
\hline P-value & \multicolumn{11}{|c|}{0.001} \\
\hline
\end{tabular}

Table (7) shows that more than three quarters of illiterate mothers (76.3\%) did nothing regarding care of wound, while the majority $(92 \%)$ of highly educated mothers practiced more than one method. The relation between mothers education and practice regarding wound care was proved to be statistically significant ( $\mathrm{p}$ value $<0.001$ ). Regarding care of bleeding (84.2\%) \& (70\%) of illiterate and "read and write" mothers did nothing, while more than three quarters of highly educated mothers $(76 \%)$ did more than one method. The relation between mothers education and practice regarding bleeding was proved to be statistically significant ( $\mathrm{p}$ value $<0.001$ ).

TABLE-8

Table (8): Relation between mother's education and her practice in case of animal bites in studied sample

\begin{tabular}{|c|c|c|c|c|c|c|c|c|c|c|c|}
\hline \multirow{2}{*}{ Mother's practice } & \multicolumn{2}{|c|}{ Illiterate } & \multicolumn{2}{|c|}{ Read \& write } & \multicolumn{2}{|c|}{ Preparatory } & \multicolumn{2}{|c|}{ Secondary } & \multicolumn{2}{|c|}{ University } & \multirow{2}{*}{ Total } \\
\hline & No. & $\%$ & No. & $\%$ & No. & $\%$ & No. & $\%$ & No. & $\%$ & \\
\hline Animal bite : & & & & & & & & & & & \\
\hline 1- Go to hospital & 7 & 18.4 & 3 & 30 & 2 & 18.2 & 4 & 9.8 & 3 & 6 & 19 \\
\hline 2- Counsel relatives & 0 & 0.0 & 0 & 0.0 & 0 & 0.0 & 0 & 0.0 & 0 & 0.0 & 0 \\
\hline 3-Traditional method & 0 & 0.0 & 1 & 10 & 0 & 0.0 & 2 & 4.9 & 5 & 10 & 8 \\
\hline 4- More than one method & 1 & 2.6 & 2 & 20 & 2 & 18.2 & 13 & 31.7 & 27 & 54 & 45 \\
\hline 5- Don't know & 30 & 78.9 & 4 & 40 & 7 & 63.6 & 22 & 53.7 & 15 & 30 & 78 \\
\hline 6- Total & 38 & 100 & 10 & 100 & 11 & 100 & 41 & 100 & 50 & 100 & 150 \\
\hline P-value & & & & & & 0.00 & & & & & \\
\hline
\end{tabular}

Table (8) clears that $(78.9 \%) \&(63.6 \%)$ respectively of illiterate and preparatory mothers did nothing regarding animal bite, while more than half $(54 \%)$ of highly educated mothers practiced more than one method. The relation between mothers education and practice regarding animal bite was proved to be statistically significant ( $\mathrm{p}$ value $<0.001$ ).

Figure - 2

Relation between mother's education and her knowledge regarding causes of home accidents

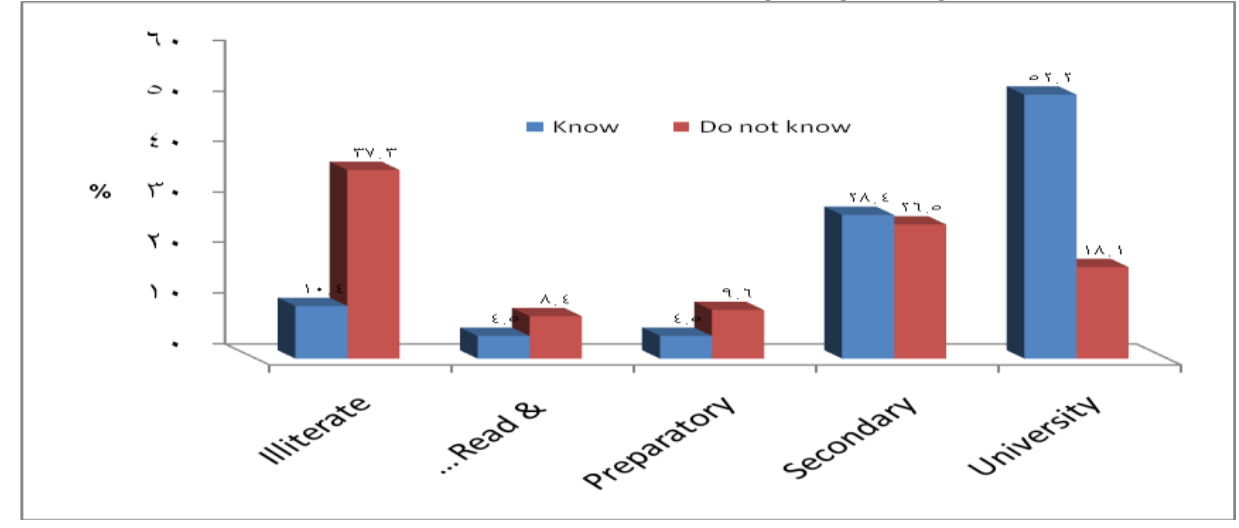


Figure 2. Shows that mother's knowledge regarding causes of home accidents increased with increasing educational level. The relation was proved to be statistically significant $(\mathrm{p}<0.001)$.

Figure 3

Relation between mother's education and her hearing about first aids

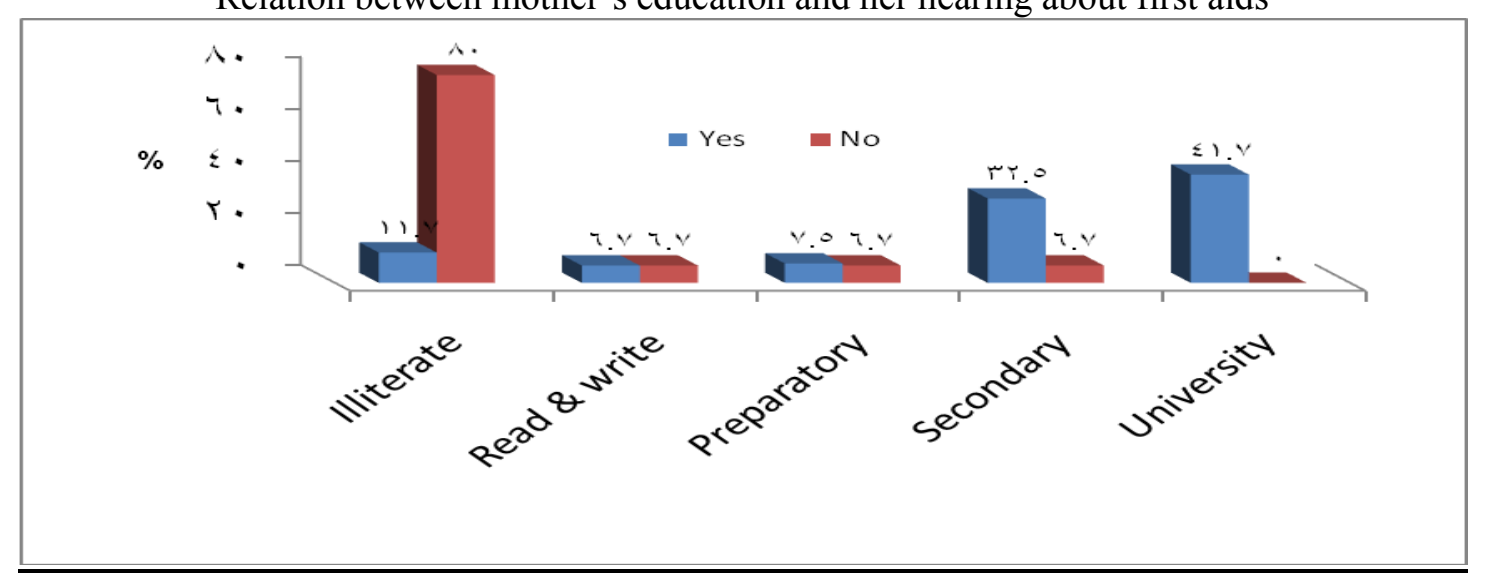

Figure3. The proportion of mothers hearing about first aid increased with increasing educational level. The relation was proved to be statistically significant $(\mathrm{p}<0.001)$

\section{Discussion}

The first five years are considered as a critical period of life where the child learns to investigate and react with his surrounding and they have curious move too much (Wong et al., 1999). Preschool children accidents are an important cause of injuries and deaths so that accidents among children under the age of five years are important problems that need active reduction intervention. So the aim of the present study was to describe the effect of mother's education in relation to home accidents prevention in rural area in Sharkia Governorate.

The present study revealed that more than half of mothers $(58 \%)$ were not working. This finding agrees with (Hussein, 2009), (Abd El-Aty., et al, 2005) and (Ibrahim, 2004) who mentioned that the majority of mothers were housewives and the home accidents rate was high among their children

Regarding the mother's age, it was found that the highest percentage of mothers $(35.3 \%)$ were in age group of 25 - < 35 years. This finding contradicted with (Hussein, 2009) who found that less than half mothers (45.3\%) were in age group of $25-29$ years. The present study revealed that nearly one quarter $(25.3 \%)$ of mothers were illiterate and this finding contradicted with (Hussein, 2009) who found in his study more than half of mothers $(52.6 \%)$ were illiterate. This difference may be related to the systematic random selection of the sample.

The results showed that the incidence of home accidents among children in a rural area in Egypt was 84.7\%. This result nearly agrees with study done in a rural community in Qalubeya Governorate revealed that the over all prevalence of injuries indoor environment were (72.6\%) among children below five years (Amin, et al., 1998) and contradicted with (Eldosoky , 2011) who found that the incidence of home related injuries among children was $38.3 \%$. This difference may be due to the difference in the age of the studied children, different methodology, study area and habits of rural area.

The current study revealed that more than half of injured children $(59.3 \%)$ were aged $\leq 3$ years, this may be due to the younger the child, the higher the frequency of household injuries. This finding contradicted with(Eldosoky , 2011) who revealed that more than half of injured children $(50.6 \%)$ were aged $9-12$ years. Regarding sex differences it was found that more than half of the injured children were boys $(58.7 \%)$ than girls $(41.3 \%)$ this result agrees with (Eldosoky , 2011) who found that the incidence rate of home accidents constituted (57.5\%) for boys and (42.5\%) for girls and also similar to study in Turkey (53.4\% for boys and $46.6 \%$ for girls) and ( ztürk C et al, 2010 )who and also agreed with (Mahalakshmy et,al , 2011 ) who found that prevalence of injury was high among male children. Differences in regional and sample characteristics may affect the statistical significance of the impact of gender in injuries (Polat S et al, 2005)

As regards types of home accidents the present study indicates that Cut/wound represented the highest percentage of home injury (37.3\%) and this agrees with ( Abd El-Aty., et al, 2005) who indicated that wounds were the most common accidents among studied children was (37.4\%). Many studies had been conducted in Assiut Governorate by Ibrahim, (2004), and Helmy, (2002) revealed that wounds represented (66.2\%, and 43.4\% respectively) among studied children. These findings were higher than the present study because of different methodology and different age structure. Other studies conducted by Hamza (2000), El-sabakhy, et al., (1981), Sadek and Ahmed (1989) and Nosseir, et al., (1990)who reported that wounds accounted for $(26.3 \%, 15.7 \%$, $14.0 \%$ and $14.9 \%$ respectively) these findings were lower than the present study . 
According to burns the present study recorded that burns represented (12\%) of the total child injuries and this agrees with Ibrahim, (2004), Hamza (2000) Amin, et al., (1998) and Laffoy (1997) who reported that burns represented $(8.2 \%, 15.4 \%, 10.5 \%$ and $13.0 \%$ respectively) of all injuries. As well as with WHO news bulletin ,the global childhood unintentional injury conducted a pilot study in 2007 as reported that burns $(13 \%)$ of childhood unintentional injury. And the present study disagrees with Helmy, et al., (2002), Nossier et al., (1990) and El-Gendawy, (1978) who mentioned that burns represented (20.2, 22.6\%and 20.4\% respectively)of injuries among preschool children. These findings were lower than the present study.

According to poisoning the present study recorded that poisoning represented (1.3\%) of the total injuries among studied children. This disagrees with another studies conducted by, Ibrahim (2004), Helmy et al., (2002), Sadek and Ahmed (1986), ( Abd El-Aty., et al, 2005) who reported that poisoning cases represented (10.9\%, 9.6\% and $7.9 \%,(7.6 \%)$ respectively) of total injuries among children.

Regarding fractures the present study recorded that fractures represented (29.3\%) this agrees with Hassan and El-Sheikh (1996) and Ibrahim, (1991) who reported that fractures accounted for $(29.0 \%$ and $30.0 \%$

respectively).and this disagreed with (Abd El-Aty., et al, 2005) who reported that fracture accounted (15.8\%)

These findings were lower than the present study.

In spite the importance of a topic like first aid, $20 \%$ of the mothers had not hear the term, and those who were familiar with it, $24 \%$ reported that T.V and radio were the sources of their knowledge and this contradicted with (Sonavane \&, Kasthuri , 2008) who reported higher proportion rate of the studied women had not heard about first aid $(65.7 \%)$ and agreed with (Eldosoky , 2011) who showed similar results regarding the source of knowledge in which T.V and radio accounted for about $45.8 \%$.

Concerning to mothers knowledge regarding causes of home accidents the current study revealed that more than half $(55.3 \%)$ of mothers didn't know causes of home accidents. This finding agreed with( Ibrahim, 1991) who revealed that more than half of the mothers $(56,0 \%)$ in the accidents group did not know anything about home accidents to which their children might be exposed and contradicted with (Abd El-Aty., et al, 2005) who found that about three quarters $(74.5 \%)$ of mothers did not know the causes of home accident and. This can attributed to the difference in the educational level of the studied samples.

Mothers' practice in different types of home accidents:

In case of fracture, wound, bleeding, the highest percentage of mothers used more than on approach in (40\%, 66,6\%, and 52\% respectively). This finding contradicted with (Hossein, 2009), who revealed that the percentage of mothers practiced more than one method constituted $(11.3 \%, 4 \%$ and $10.8 \%$ respectively) and (Abd El-Aty., et al, 2005) who revealed that the percentage of mothers practiced more than one method constituted $(11.7 \%, 4.5 \%$, and $10.5 \%)$ respectively. This difference may be related to the difference of educational level of the studied sample.

Regarding mothers' practice in case of choking, poisoning, animal bite, and burn, results of the current study showed that going to hospital constituted $20 \%, 20.7 \%, 12.7 \%$ and $14.7 \%$ respectively of mothers answers and this contradicted with( Hossein, 2009), (Abd El-Aty., et al, 2005) and (Ibrahim, 2004). Who reported that the highest percentage of mothers going to hospital in case of choking, poisoning, animal bite, and burn.

As regarding to relation between mother's education and their practices regarding care of poisoning, choking, burn, fracture, wound, bleeding and animal bite there was statistically significant difference where with higher educational level there were good practices

Regarding to relation between mother's education and their knowledge regarding causes of home accidents among children, the present study revealed that illiterate mothers did not have knowledge about causes of home accidents $(37.3 \%)$ compared to $(52.2 \%)$ of university educated mothers who had knowledge regarding causes of home accidents and this agreed with (Hossein, 2009), (Abd El-Aty., et al, 2005) and (Helmy, 2002). Who reported that illiterate mother's failed to obtain knowledge regarding home accidents.

\section{Conclusion}

Although home accidents are a common problem among preschool children, mothers' knowledge regarding home accidents were deficient and the mothers' education was variable significantly in relation with mothers' knowledge regarding home accidents. As well as the relation between mother's education and their practices in first aid was statistically significant with higher educational level.

\section{Recommendations}

1- Increase public awareness regarding home accidents through mass media.

2- Health education program for mothers about safe housing condition should be held in MCHC

3- Health education program about causes of home accidents, first aid management and method of prevention into the curriculum at different levels. 


\section{References}

[1]. Krug EG, Sharma GK, Lozano R: The global burden of injuries. Am J Public Health 2000, 90:523-526.

[2]. Bruce B, McGrath P: Group interventions for the prevention of injuries in young children: a systematic review. Inj Prev 2005, 11:143-147. PubMed Abstract .

[3]. Amin M, Abd El-Moneim M, Hafez A. Epidemiological study of preschool injuries in rural community, Qalubeya Governorate.Egyptian Journal of Community Medicine, 1998, 16:31-41.

[4]. Abd El-Aty NS et al. Assessment of knowledge and practice of mothers towards home accidents among children under six years in Assiut governorate. Assiut University Bulletin for Environmental Research, 2005, 8(2):11-28.

[5]. National Safe Kids Campaign [online factsheet] http://www.achd.net/injury/pubs/pdf/KidsSafety_pamphlet.pdf, accessed 9 August 2012).

[6]. WHO Issue Brief Series: Accidents and Injuries Healthy Environments for Children Alliance Available from www.who.int/heca/ accessed 7 December 2013

[7]. Home Accident Presentation Strategy \& Action Plan 2004 - 2009 3SQ Published by: Department of Health, Social Services and Public Safety, Castle Buildings, Belfast BT4 3SQ aviliable from www.dhsspsni.gov.uk/ november 2004 accede at 7december 2013

[8]. Abd El-Wahed M A, Mitwally H H, \& Mahmoud N M, (2000): "Preventive program for home injuries among rural children in Egypt and Oman". Alexandria journal of pediatrics, 14 (1), pp. 65-71.

[9]. Tomruk O et al. First aid: level of knowledge of relatives and bystanders in emergency situations. Advances in Therapy,2007, 24:691-699.

[10]. Hecht BK. First aid: from witchdoctors and religious knights to modern doctors. MedicineNet.com [online factsheet] (http://www. medicinenet.com/script/main/art.asp?articlekey=52749, accessed 9 August 2012).

[11]. Ibrahim A. Assessment of knowledge, attitude and practice of mothers attending Cairo University Hospital toward home accidents among preschool children [MSc thesis]. Cairo, Egypt, Higher Institute of Nursing, University of Cairo, 1991.

[12]. National safe kids campaign, (2000). National SAFE KIDS Campaign promoting child safety to prevent unintentional injuries. www. safekids.org.

[13]. Wong D L, Eaton M H, Winkelstein M L, Wilson D, Ahmann E, \& Thomas P, (1999): "Nursing care of infants and children, health promotion of the preschooler and family", (6th ed.). Mosby, New York, pp. 613-615.

[14]. Hossien, YE , (2009). Effect of mother's education in relation to home accident prevention among preschool children in rural area in EL-Minia Governorate. EL-Minia MED. BULL. VOL. 20, NO. 2, JUNE, 2009

[15]. Abd El-Aty NS et al. Assessment of knowledge and practice of mothers towards home accidents among children under six years in Assiut governorate. Assiut University Bulletin for Environmental Research, 2005, 8(2):11-28.

[16]. Ibrahim H H, (2004): "Investigative epidemiology of childhood accidents in El-Fateh district", Assiut Governorate, Upper gypt. Doctor Thesis, Faculty of Medicine, Assiut University.

[17]. Amin M, Abd El-Moneim M, Hafez A. Epidemiological study of preschool injuries in rural community, Qalubeya Governorate. Egyptian Journal of Community Medicine, 1998, 16:31-41.

[18]. Eldosoky , R.S.H , (2011). Home - related injuries among children: knowledge, attitudes and practice about first aid among rural mothers.

[19]. Mahalakshmy T, Dongre AR, Kalaiselvan G. Epidemiology of childhood injuries in rural Pondicherry, South India. Indian Journal of Pediatrics, 2011, 78:821-825.

[20]. Polat $S$ et al. locuk acil kliniğine başvuran 0-18 yaş grubu olguların incelenmesi [Analysis of patients aged 0-18 years admitted to the emergency department]. Atatürk Üniversitesi Hemşirelik Yüksekokulu Dergisi, 2005, 8:55-56.

[21]. Facts of life, 3rd ed. New York, United Nations Children's Funds, 2002:176.

[22]. Helmy F E, Labeeb S A, \& Shafie I F, (2002): "Assessment of home environmental risk factors regarding accidents among preschool children. Assiut University", Bulletin for environmental researchers: 5 (1), pp. 21-29.

[23]. Hamza W S, (2000): "Epidemiology of accidents among children in a village in Assiut Governorate". Master Thesis public Health and Preventive Medicine, Faculty of Medicine, Assiut University.

[24]. El-Sebakh H, Fahmi S I, Tantawy A S, \& Moustafa K, (1981): "Reported accidents of university students in Alexandria University health services". Bulletin of High Institute of Public Health in Alexandria, 9: 353-366.

[25]. Nossier S, Sherif A A, Mortuda M M, Dobbous N I, \& El-Shan F F, (1990): "A study of accidents among preschool children attending MCH centers in Alexandria". Alexandria J. of Pediatrics, (4): 45-48.

[26]. Laffoy M, (1997): "Childhood accidents at home". Ir. Med. J. 1997. Jan. Feb, 90 (1): 26-27.

[27]. El-Gendawy H A S, (1978): "Exploration of the predominant external causes of burns attended to the major medical centers in Assiut". Thesis for M P H, Assiut University

[28]. Ahmed H, (1989): "Study to assess safety measures adopted at home to prevent poisoning among children under five years of age". Master thesis Public Health Nursing. Higher Institute of Nursing, University of Alexandria.

[29]. Ibrahim A, (1991): "Assessment of knowledge, attitude and practice of mothers attending Cairo University Hospital toward home accidents among preschool children. Master Thesis in Nursing", Higher Institute of Nursing, Cairo University.

[30]. Hassan F \& El-Sheikh E, (1996): "Surveillance of trauma in Port- Said", Egypt. Comm- Med-Dept. Faculty of Medicine Suez Canal University, Ismailia, Egypt.

[31]. Sonavane R, Kasthuri A. Knowledge, attitude and practice of first aid among women in a rural area [MD thesis]. Bangalore, India, Department of Community Health, Bangalore University, 2008.

[32]. Helmy F E, Labeeb S A, \& Shafie I F, (2002): "Assessment of home environmental risk factors regarding accidents among preschool children. Assiut University", Bulletin for environmental researchers: 5 (1), pp. 21-29. 